\title{
Pradefovir Mesylate
}

National Cancer Institute

\section{Source}

National Cancer Institute. Pradefovir Mesylate. NCI Thesaurus. Code C66454.

The mesylate salt form of pradefovir, a cyclodiester antiviral prodrug with specific activity against hepatitis B virus (HBV). Pradefovir is specifically metabolized in the liver by hepatic enzymes, mainly by CYP4503A4, to adefovir. In turn, adefovir is phosphorylated by cellular kinases to its activated form adevofir diphosphate. By competing with the natural substrate dATP, the diphosphate form is incorporated into viral DNA and inhibits RNAdependent DNA polymerase. This causes DNA chain termination and eventually results in an inhibition of HBV replication. 